\title{
Correction to: Neuropilin-1 receptor in the rapid and selective estrogen-induced neurovascular remodeling of rat uterus
}

\author{
Analía Richeri $^{1,2} \cdot$ Gabriela Vierci $^{1} \cdot$ Gaby Fabiana Martínez $^{1} \cdot$ María Paula Latorre $^{1} \cdot$ Cora Chalar $^{3}$. \\ María Mónica Brauer ${ }^{1}$
}

Published online: 15 June 2020

(C) Springer-Verlag GmbH Germany, part of Springer Nature 2020

\section{Correction to: Cell and Tissue Research https://doi.org/10.1007/s00441-020-03196-8}

The article title of the original publication contains an error for the term "estrogen" was captured twice. The corrected version of the title is presented above.

The original article has been corrected.

The online version of the original article can be found at https://doi.org/ 10.1007/s00441-020-03196-8

\section{Analía Richeri \\ aricheri@iibce.edu.uy}

1 Laboratory of Cell Biology, Instituto de Investigaciones Biológicas, Clemente Estable (IIBCE), Avenida Italia 3318, 11600 Montevideo, ZP, Uruguay

2 Department of Experimental Neuropharmacology, Instituto de Investigaciones Biológicas Clemente Estable (IIBCE), Avenida Italia, 3318, 11600 Montevideo, ZP, Uruguay

3 Sección Bioquímica, Instituto de Biología, Facultad de Ciencias,UdelaR, Montevideo, Uruguay 